\title{
Effect of Cadmium on Growth, Bacoside A, and Bacopaside I of Bacopa monnieri (L.), a Memory Enhancing Herb
}

\author{
Poonam Gupta, ${ }^{1}$ Sayyada Khatoon, ${ }^{2}$ P. K. Tandon, ${ }^{1}$ and Vartika Rai ${ }^{1}$ \\ ${ }^{1}$ Department of Botany, University of Lucknow, Lucknow, Uttar Pradesh 226007, India \\ ${ }^{2}$ Pharmacognosy and Ethnopharmacology Division, CSIR-National Botanical Research Institute, Lucknow, \\ Uttar Pradesh 226001, India \\ Correspondence should be addressed to Poonam Gupta; poonam_gupta03@yahoo.co.in
}

Received 24 August 2013; Accepted 28 October 2013; Published 30 January 2014

Academic Editors: C. Hocart and G. L. Rotino

Copyright (C) 2014 Poonam Gupta et al. This is an open access article distributed under the Creative Commons Attribution License, which permits unrestricted use, distribution, and reproduction in any medium, provided the original work is properly cited.

\begin{abstract}
Bacopa monnieri (L.) is an important medicinal plant mainly known as a memory enhancing herb. It is important to see the effect of metal pollution on its active constituents. In this context, efforts have been made to observe the effect of Cd on the triterpenoid saponins bacoside A and bacopaside I in this plant. The influence of the metal on growth parameters like protein, chlorophyll content, and biomass has also been observed. It is interesting to note that the bacoside A and bacopaside I gradually increased by the Cd treatment up to $10 \mu \mathrm{M}$ and then decreased at higher concentrations, that is, 50 and $100 \mu \mathrm{M}$, but the concentration of these components was more in all the treated plants as compared to control. On the contrary, protein, chlorophyll content, and biomass decreased with the increase in metal concentration and exposure duration due to metal toxicity.
\end{abstract}

\section{Introduction}

Bacopa monnieri (L) Pennell (Fam. Scrophulariaceae) is growing in the marshy places, which may be natural, or manmade with high possibility of heavy metal contamination as manmade marshy places are generally created in industrial areas where industrial effluents were discharged with high metal content. In such places one can see the luxuriant growth of B. monnieri. In this context, it becomes necessary to check the effect of heavy metals on general growth and active constituents of the plant, because demand of this plant is quite high in market and plant collectors collect it without considering polluted or nonpolluted site. Cadmium is one of the heavy metals that is of great concern in the environment because of its toxicity to all the plants, animals, and human beings. Cd enters in the environment through industrial waste from processes such as electroplating, manufacturing of plastics, mining, paint pigments, alloy preparation, and batteries that contain cadmium $[1,2]$. Cadmium is also used for luminescent dials, in photography and rubber curing, and as fungicides [1]. The most likely origin of the excess $\mathrm{Cd}$ is from heavy applications of cheap, contaminated phosphate fertilizers $[3,4]$. It is considered to be highly mutagenic and designated as human carcinogen by International Agency for Research on Cancer $[5,6]$. It is retained for many years in the human body and may induce chronic toxicity $[7,8]$. Elevated levels of $\mathrm{Cd}$ in humans can cause kidney damage, and low levels of $\mathrm{Cd}$ in the diet are linked renal to dysfunction. Other diseases associated with $\mathrm{Cd}$ exposure are pulmonary emphysema and the notorious Itai-Itai ("ouch-ouch") disease [9]. Therefore, effective and economical techniques are needed to remediate $\mathrm{Cd}$-contaminated soils.

$B$. monnieri is a small creeping herb, commonly growing in marshy places up to an altitude of $1500 \mathrm{~m}$. It is an important Ayurvedic drug and traditionally it is reported to be used in skin diseases, fever, inflammation, anaemia, urinary disorder, and psychiatric disorders [10]. It is also considered to be cardiotonic, a potent nervine tonic, and useful for asthma, hoarseness, insanity, and epilepsy [11]. Ethnobotanically the leaves are used in speech disorders [12]; in premature ejaculation [13]; flatulence [14]; abdominal pain [15]; cough and cold [16-18], and leaf juice is used in rheumatism $[19,20]$ revitalizer of intellectual faculty [21]. The major therapeutically important chemical constituents of this plant are triterpenoid 
TABLE 1: Effect of cadmium on biomass ( $\mathrm{g} f \mathrm{w}$ ) in B. monnieri at different concentrations and exposure periods.

\begin{tabular}{lcccc}
\hline Cd concentrations $(\mu \mathrm{M})$ & \multicolumn{4}{c}{ Exposure periods $(\mathrm{h})$} \\
& 0 & 48 & 96 & 168 \\
\hline $0 \mu \mathrm{M}$ & $1.81 \pm 0.14$ & $1.87 \pm 0.17$ & $2.07 \pm 0.25$ & $2.14 \pm 0.24$ \\
$5 \mu \mathrm{M}$ & $2.03 \pm 0.11$ & $2.06 \pm 0.12$ & $2.08 \pm 0.03$ & $2.17 \pm 0.03$ \\
$10 \mu \mathrm{M}$ & $1.75 \pm 0.52$ & $1.75 \pm 0.52$ & $1.79 \pm 0.52$ & $1.86 \pm 0.57$ \\
$50 \mu \mathrm{M}$ & $1.53 \pm 0.42$ & $1.52 \pm 0.42$ & $1.20 \pm 0.23^{\mathrm{A}}$ & $1.13 \pm 0.16^{\mathrm{a}}$ \\
$100 \mu \mathrm{M}$ & $1.31 \pm 0.19$ & $1.31 \pm 0.19$ & $0.98 \pm 0.07^{\mathrm{B}}$ & $0.94 \pm 0.06^{\mathrm{b}}$ \\
\hline
\end{tabular}

All values are means of triplicate \pm SD.

A denote the significance $(P<0.05)$ at $50 \mu \mathrm{M}$ cadmium as compared to control after 96 hours.

${ }^{\mathrm{B}}$ denotes the significance $(P<0.01)$ at $100 \mu \mathrm{M}$ cadmium as compared to control after 96 hours.

a denotes the significance $(P<0.05)$ at $50 \mu \mathrm{M}$ cadmium as compared to control after 168 hours.

b denotes the significance $(P<0.05)$ at $100 \mu \mathrm{M}$ cadmium as compared to control after 168 hours.

saponins bacosides. The pharmacological $[22,23]$ and clinical studies $[24,25]$ on the extract and bacoside $A$ and $B$ have been published. The extracts have economic importance too as it is widely available in the international nutraceutical markets.

Although some reports are available on the accumulation and toxicity of heavy metals in B. monnieri [26-32], but no report is available on the effect of $\mathrm{Cd}$ on the active principles of B. monnieri. Keeping this in mind an attempt was made to check the effect of Cd on growth and active constituents of $B$. monnieri, that is, bacoside A and bacopaside I.

\section{Material and Methods}

Plants of Bacopa monnieri were collected from unpolluted sites and grown in hydroponic cultures for several months in the field laboratory. The healthy vegetative clones of $B$. monnieri were further acclimatized in $3 \%$ Hoaglands' nutrient medium [33] under standard physiological conditions providing $16 \mathrm{hrs}$ light period $\left(114 \mu \mathrm{mol} \mathrm{M}^{-2} \mathrm{~s}^{-1}\right)$ and $8 \mathrm{hrs}$ dark photoperiod, $26 \pm 2^{\circ} \mathrm{C}$ for 6 weeks.

Different concentrations of $\mathrm{Cd}$, that is, $5 \mu \mathrm{M}, 10 \mu \mathrm{M}$, $50 \mu \mathrm{M}$, and $100 \mu \mathrm{M}$, were prepared in $3 \%$ Hoagland's solution using AR grade cadmium chloride $\left(\mathrm{CdCl}_{2}\right)$. Only $3 \%$ Hoagland's solution without addition of Cd served as control. Young plants of B. monnieri with 14-16 internodes and 23 basal rooted nodes were incorporated in each concentration under the abovementioned standard physiological conditions. The whole experiment was repeated at least three times. Aeration was provided to all the plants. The plants were harvested after 48,96 , and $168 \mathrm{hrs}$ for estimation of metal uptake, protein and chlorophyll content, and biomass (fresh weight). Bacoside A and bacopaside I contents were measured in control, $5 \mu \mathrm{M} 10 \mu \mathrm{M}, 50 \mu \mathrm{M}$, and $100 \mu \mathrm{M} \mathrm{Cd}$ concentrations after one week.

Biomass was calculated on fresh weight basis using electronic balance. The fresh plant was used for the estimation of chlorophyll content. $100 \mathrm{mg}$ fresh weight of the plant was extracted in $80 \%$ chilled acetone and estimated following the method of Arnon [34]. Protein content in the plants of $B$. monnieri was estimated by the method of Lowry et al. [35] using bovine serum albumin (BSA) as a standard. For metal uptake the harvested plant material was washed with deionized water, weighed and dried at $70^{\circ} \mathrm{C}$ for $48 \mathrm{hrs}$, and digested with $\mathrm{HNO}_{3}: \mathrm{HCLO}_{4}(10: 1 \mathrm{v} / \mathrm{v}$ mixture). Cd was estimated using Perkin Elmer 2380 Atomic Absorption Spectrophotometer (detection limit of Cd: $0.0005 \mathrm{ppm}$ ).

For quantitative thin layer chromatography (TLC) for bacoside A and bacopaside I, ten grams of powdered plant material of control and Cd treated plant was extracted with $50 \mathrm{~mL}$ methanol on water bath consecutively three times. Extracts were filtered and concentrated at low temperature and reduced pressure. Bacoside A and bacopaside I standard solutions of $1 \mathrm{mg} / \mathrm{mL}$ concentration were prepared by dissolving the standards in methanol. $10 \mu \mathrm{L}$ of standards and plant extracts was applied on HPTLC precoated silica gel plates (EMERCK $\mathrm{F}_{254}$ ) with the help of CAMAG Linomat V Applicator. The plates were developed to a distance of $9.0 \mathrm{~cm}$ in the solvent system Chloroform: Methanol: Water $(7: 3: 0.5)$ in previously saturated twin trough chamber (CAMAG). The plates were scanned at the wave length $500 \mathrm{~nm}$ using CAMAG TLC Scanner 3 with software winCATS. Photographs of TLC plates were taken by the CAMAG Reprostar-3.

2.1. Statistical Analysis. The experiment was set up as randomized block design. To confirm the variability of data and validity of results all the data were subjected to analysis of variance (ANOVA) followed by Newman Keuls' test for individual comparison. Comparison between control and treatment was done by LSD test [36].

\section{Results and Discussion}

Higher Cd treatments, that is, 50 and $100 \mu \mathrm{M}$, produce visible morphological symptoms like decay of basal portion of shoot and leaves due to Cd toxicity after one week. The intensity of Cd toxicity enhanced with increase in the exposure duration. Browning and stunting of roots were also observed in $50 \mu \mathrm{M}$ $\mathrm{Cd}$ and above after one week. The significant decrease in the biomass of plant is also observed at higher concentrations $(P<0.05)$ (Table 1). Decrease in biomass also confirms that $\mathrm{Cd}$ affects the growth of plants at higher concentrations. This is in accordance with the studies of Haag-Kerwer et al., [37] in which $\mathrm{Cd}$ accumulation results in the decrease in growth rate 
TABLE 2: Effect of cadmium on the chlorophyll content $\left(\mathrm{mg} \mathrm{g}^{-1} \mathrm{fw}\right)$ in B. monnieri at different concentrations and exposure periods.

\begin{tabular}{lcrr}
\hline Cd concentration $(\mu \mathrm{M})$ & \multicolumn{3}{c}{ Exposure periods (h) } \\
\hline 0 & 48 & $1.36 \pm 0.04$ & 168 \\
$5 \mu \mathrm{M}$ & $1.23 \pm 0.02$ & $1.32 \pm 0.02^{\mathrm{B}}$ & $1.37 \pm 0.03$ \\
$10 \mu \mathrm{M}$ & $1.25 \pm 0.03^{\mathrm{A}}$ & $1.22 \pm 0.02^{\mathrm{B}}$ & $1.36 \pm 0.01^{\mathrm{C}}$ \\
$50 \mu \mathrm{M}$ & $1.24 \pm 0.04^{\mathrm{A}}$ & $0.99 \pm 0.01^{\mathrm{B}}$ & $1.10 \pm 0.02^{\mathrm{C}}$ \\
$100 \mu \mathrm{M}$ & $1.21 \pm 0.01^{\mathrm{A}}$ & $.72 \pm 0.01^{\mathrm{B}}$ & $0.74 \pm 0.02^{\mathrm{C}}$ \\
\hline
\end{tabular}

All values are means of three replicates \pm SD; LSD $P<0.01$.

A denotes significance $(P<0.01)$ at different $\mathrm{Cd}$ concentrations as compared to control after 48 hours.

${ }^{\mathrm{B}}$ denotes significance $(P<0.01)$ at different $\mathrm{Cd}$ concentrations as compared to control after 96 hours. ${ }^{\mathrm{C}}$ denotes significance $(P<0.01)$ at different $\mathrm{Cd}$ concentrations after 168 hours.

TABLE 3: Effect of $\mathrm{Cd}$ on the protein content $\left(\mathrm{mg} \mathrm{g}^{-1} \mathrm{fw}\right)$ of B. monnieri at different concentrations and exposure periods.

\begin{tabular}{lcrr}
\hline Cd concentration $(\mu \mathrm{M})$ & \multicolumn{3}{c}{ Exposure periods (h) } \\
\hline Control 0 & 48 & $12.33 \pm 0.01$ & 168 \\
$5 \mu \mathrm{M}$ & $12.33 \pm 0.04$ & $11.09 \pm 0.01^{\mathrm{A}}$ & $12.50 \pm 0.08$ \\
$10 \mu \mathrm{M}$ & $11.99 \pm 0.01^{\mathrm{A}}$ & $11.54 \pm 0.20^{\mathrm{A}}$ & $10.21 \pm 0.01^{\mathrm{A}}$ \\
$50 \mu \mathrm{M}$ & $11.80 \pm 0.09^{\mathrm{A}}$ & $8.09 \pm 0.01^{\mathrm{A}}$ & $9.25 \pm 0.01^{\mathrm{A}}$ \\
$100 \mu \mathrm{M}$ & ${ }^{\mathrm{A}} 10.07 \pm 0.03^{\mathrm{A}}$ & $7.51 \pm 0.01^{\mathrm{A}}$ & $7.06 \pm 0.03^{\mathrm{A}}$ \\
\hline
\end{tabular}

All the values are means of three replicates, LSD $P<0.01$; ${ }^{\mathrm{A}}$ denotes significance $(P<0.01)$ at different $\mathrm{Cd}$ concentrations and exposure periods as compared to control.

TABLE 4: Accumulation of $\mathrm{Cd}\left(\mu \mathrm{g} \mathrm{g}^{-1} \mathrm{dw}\right)$ in B. monnieri at different concentrations and exposure periods.

\begin{tabular}{lccc}
\hline Cd concentrations $(\mu \mathrm{M})$ & \multicolumn{3}{c}{ Exposure periods (h) } \\
\hline 0.0 & 48 & 96 & $\mathrm{ND}$ \\
$5 \mu \mathrm{M}$ & $\mathrm{ND}$ & $280.35 \pm 25.34$ & $330.07 \pm 31.58$ \\
$10 \mu \mathrm{M}$ & $169.91 \pm 3.05$ & $667.62 \pm 47.13$ & $718.56 \pm 2.74$ \\
$50 \mu \mathrm{M}$ & $290.32 \pm 19.08$ & $1140.16 \pm 33.92$ & $1729.21 \pm 50.23$ \\
$100 \mu \mathrm{M}$ & $584.47 \pm 51.55$ & $1303.07 \pm 84.41$ & $1779.91 \pm 49.07$ \\
\hline
\end{tabular}

All values are means of triplicate \pm SD; LSD $P<0.01$.

and reduction in transpiration of mustard plants. A significant $(P<0.01)$ decrease in the chlorophyll content with the increase in the metal concentration (Table 2) was observed in the present study. This might be due to interaction of Cd with -SH group of various enzymes involved in the chlorophyll biosynthesis [38]. The decrease in the protein content of the plant with increase in the metal concentration was also highly significant $(P<0.01)$ (Table 3$)$. A significant decrease in the protein content may be due to $\mathrm{Cd}$-induced oxidation of proteins mediated by $\mathrm{H}_{2} \mathrm{O}_{2}$ and due to increased proteolytic activity which has been proposed as an index of oxidative stress [39].

The uptake of $\mathrm{Cd}$ by the plant was doze and duration dependent and also highly significant $(P<0.01)$. At the lowest ambient concentration of $5 \mu \mathrm{M}$ the uptake was as high as $169.91 \mu \mathrm{g} / \mathrm{g}$ dry wt, within $48 \mathrm{hrs}$. However maximum uptake was $1779.70 \mu \mathrm{g} / \mathrm{g}$, after $168 \mathrm{~h}$ observed in $100 \mu \mathrm{M}$ concentrations (Table 4). Although Cd is a highly toxic metal for the growth and development of plant but it is highly accumulated by aquatic macrophytes, which has also been previously reported by various workers [40-44]. Accumulation of cadmium by $B$. monnieri has also been reported
TABLE 5: $R_{f}$ values and the colour of components present in $B$. monnieri extracts.

\begin{tabular}{lc}
\hline Colour & $R_{f}$ \\
\hline Yellowish brown & 0.20 \\
Brown (I) & $\mathbf{0 . 2 6}$ bacopaside I \\
Yellow & 0.39 \\
Purple blue (a) & $\mathbf{0 . 5 7}$ bacoside A \\
Blue (a) & $\mathbf{0 . 6 0 ~ A ~}$ \\
Light blue & 0.67 \\
Light blue & 0.71 \\
Light blue & 0.78 \\
Greenish & 0.82 \\
\hline
\end{tabular}

Bold fonts refer to $R_{f}$ s of Bacoside and Bacopaside.

earlier by Sinha and Chandra [26]; Sinha [29]; Ali et al. [30]; and Singh et al. [32]. It can be said with these results that B. monnieri can work as potential accumulator of $\mathrm{Cd}$ and can be used in the phytoremediation. Phytoremediation is the use of green plants to detoxify a degraded or polluted environment [45]. The main advantages of phytoremediation 


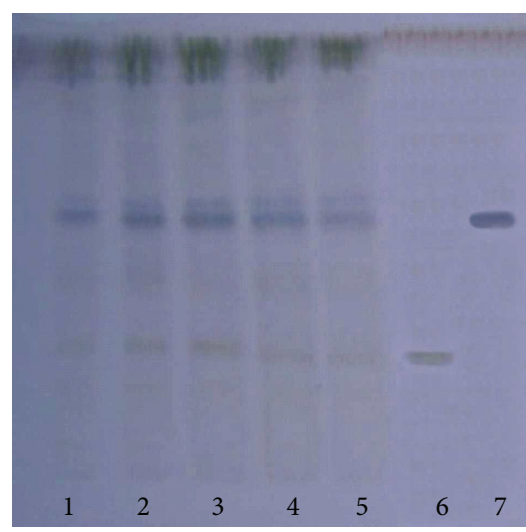

(a)

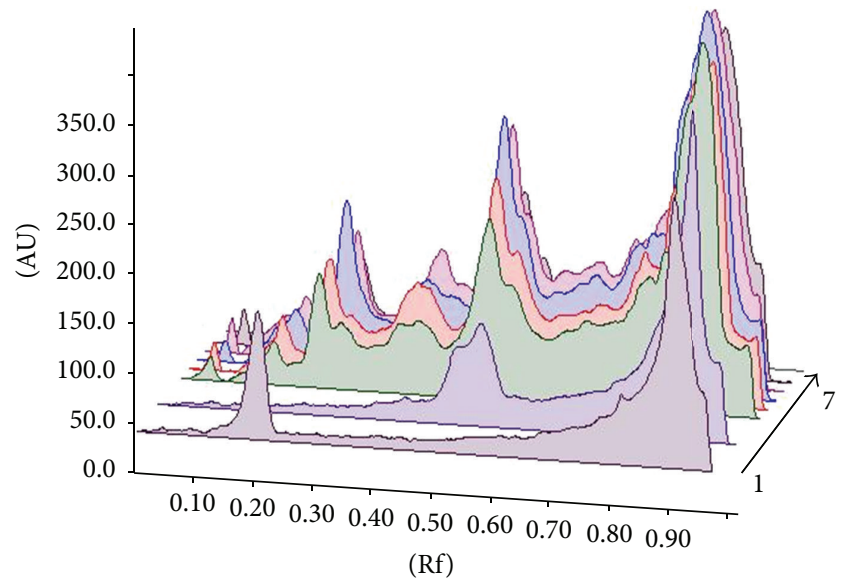

(b)

FIGURE 1: TLC of methanolic extract of control and Cd treated plants of Bacopa monnieri. (a) Fingerprint profile, 1: control, 2: $5 \mu \mathrm{M} \mathrm{Cd}, 3$ : $10 \mu \mathrm{M} \mathrm{Cd}, 4: 50 \mu \mathrm{M}$ Cd, 5: $100 \mu \mathrm{M}, 6$ : bacoside A, and 7: bacopaside I. (b) Densitometric scan at $500 \mathrm{~nm}$.

are that the procedure is carried out in situ and it is inexpensive compared to other technologies for remediation [45]. Another important advantage of phytoremediation is that soils retain their fertility after metal removal.

The TLC fingerprint profile showed the increase in the content of the bioactive compounds, that is, bacoside $\mathrm{A}$ and bacopaside I in all Cd treated plants (Figure 1). The retention factor values and the colour of components present in $B$. monnieri extracts are shown in Table 5.

It is a well-known fact that secondary metabolites are formed under various stresses as a defense mechanism [46]. In the present study it is interesting to note that the aforesaid compounds were gradually increased by the $\mathrm{Cd}$ treatment up to $10 \mu \mathrm{M}$ and then decreased at higher concentrations, that is, $50 \mu \mathrm{M}$ and $100 \mu \mathrm{M}$ (Figure 2). This indicates that the synthesis of secondary metabolites enhances initially up to a certain limit due to abiotic stress and then decreases due to $\mathrm{Cd}$ toxicity in higher concentrations. There are several examples available where plants synthesize and accumulate secondary metabolites upon treatment with heavy metals [47-50].

Thus, it is clear from this study that B. monnieri may become a very important plant for phytoremediation and

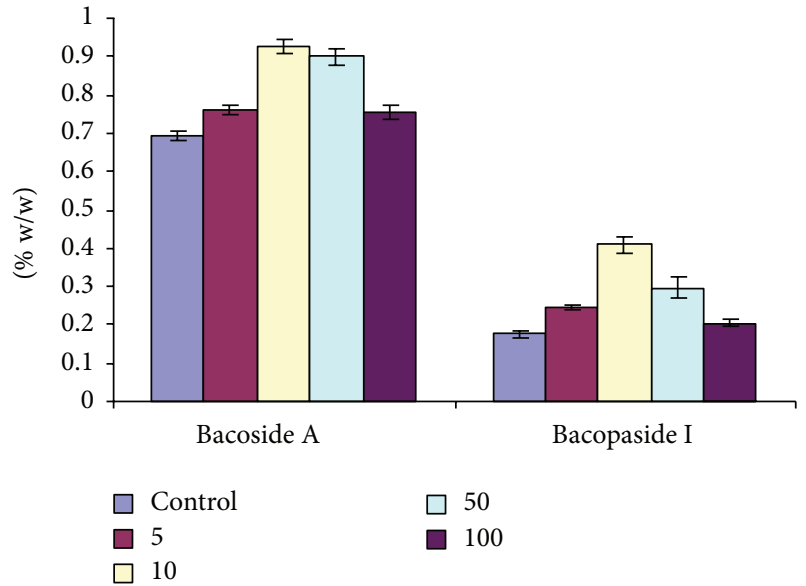

FIGURE 2: Effect of cadmium on the bacoside A and bacopaside I content in B. monnieri.

remove Cd from the polluted site, and it is a good indication that its active constituents increase in this condition. Pharmaceutical companies may use these plants for extracting its active compounds, even if grown on polluted sites.

\section{Conflict of Interests}

The authors declare that there is no conflict of interests regarding the publication of this paper.

\section{Acknowledgments}

P. Gupta acknowledges Department of Science and Technology, New Delhi, for financial support under Women Scientist Scheme. The authors are thankful to the Director of National Botanical Research Institute, Lucknow, for all his encouragement and necessary facilities. P. Gupta acknowledges the support and keen interest shown by the Head the Department of Botany Lucknow University and acknowledges him for providing the basic facilities.

\section{References}

[1] D. C. Adriano, Trace Elements in Terrestrial Environments. Biogeochemistry, Bioavailability, and Risks of Metals, Springer, New York, NY, USA, 2001.

[2] B. Cordero, P. Lodeiro, R. Herrero, and M. E. Sastre de Vicente, "Biosorption of cadmium by fucus spiralis," Environmental Chemistry, vol. 1, no. 3, pp. 180-187, 2004.

[3] B. Booth, "The added danger of counterfeit cigarettes," Environmental Science \& Technology, vol. 39, no. 2, article A34, 2005.

[4] W. E. Stephens, A. Calder, and J. Newton, "Source and health implications of high toxic metal concentrations in illicit tobacco products," Environmental Science and Technology, vol. 39, no. 2, pp. 479-488, 2005.

[5] IARC, "Beryllium cadmium Mercury exposure in glass manufacturing industry," Monographs on evaluation of carcinogenic risk to humans, vol. 58, pp. 119-239, IARC, Lyon, France, 1993. 
[6] M. Filipič and T. K. Hei, "Mutagenicity of cadmium in mammalian cells: implication of oxidative DNA damage," Mutation Research, vol. 546, no. 1-2, pp. 81-91, 2004.

[7] A. P. Jackson and B. J. Alloway, "The transfer of cadmium from agricultural soils to the human food chain," in Biogeochemistry of Trace Metals, D. C. Adriano, Ed., Lewis Publishers, Boca Raton, Fla, USA, 1992.

[8] FAO/WHO, "Joint committee on food additives and contaminants," Position Paper on Cadmium, SPB Acadamic, Hague, The Netherlands, 1995.

[9] A. T. Yeung and C.-N. Hsu, "Electrokinetic remediation of cadmium-contaminated clay," Journal of Environmental Engineering, vol. 131, no. 2, pp. 298-304, 2005.

[10] API, Ayurvedic Pharmacopoeia of Part I, vol. 2, Ministry of Health and family welfare Government of India, India, 1999.

[11] R. N. Chopra, S. L. Nayar, and I. C. Chopra, Glossary of Indian Medicinal Plants, CSIR, New Delhi, India, 6th edition, 2002.

[12] A. S. Upadhya, V. D. Vartak, V. Kamboj, and M. S. Kar, "Ethnomedico botanical studies in Western Maharashtra India," Ethnobotany, vol. 6, pp. 25-31, 1994.

[13] K. Mohan and A. K. Singh, "Ethno-medico-botany of Tharus," Advances in Plant Science, vol. 9, pp. 1-6, 1996.

[14] K. M. Chetty, M. L. Chetty, A. Sudhakar, and C. Ramesh, "Ethno-medico botany of some aquatic angiospermae in Chittoor district of Andhra Pradesh, India," Fitoterapia, vol. 69, no. 1, pp. 7-12, 1998.

[15] A. Pareek, "Preliminary ethnobotanical notes on the plants of aquatic habitats of Rajasthan," Journal of Phytolological Research, vol. 7, pp. 73-76, 1994.

[16] S. K. Malhotra and S. Moorthy, "Some useful and medicinal plants of Chandrapur district (Maharashtra state)," Bulletin of Botanical Survey India, vol. 15, pp. 13-21, 1973.

[17] P. B. Singh and B. S. Aswal, "Medicinal plants of Himachal Pradesh used in Indain pharmaceuticals (Bacopa monniera Wettst.) Part I," Journal of Research in Ayurveda and Siddha, vol. 1, pp. 133-148, 1992.

[18] P. B. Singh, "Medicinal plants of Ayurvedic importance from Mandi district of Himachal Pradesh," Bulletin of Medicinal and Ethnobotanical Research, vol. 13, pp. 172-208, 1993.

[19] S. J. Bedi, "Ethnobotany of the Ratan Mahal Hills, Gujarat, India," Economic Botany, vol. 32, no. 3, pp. 278-284, 1978.

[20] G. L. Shah, A. R. Menon, and G. V. Gopal, "An account of the Ethnobotany of Saurashtra in Gujarat state (India)," Journal of Economic and Taxonomy Botany, vol. 2, pp. 173-182, 1981.

[21] R. Sharma, C. Chaturvedi, and P. V. Tewari, "Efficiency of Bacopa monnieri inrevitalizing intellectual function in children," Journal Research Edn Ind Medica, vol. 6, pp. 1-10, 1987.

[22] H. K. Singh, R. P. Rastogi, R. C. Srimal, and B. N. Dhawan, "Effect of bacosides A and B on avoidance responses in rats," Phytotherapy Research, vol. 2, no. 2, pp. 70-75, 1988.

[23] H. K. Singh and B. N. Dhawan, "Neuropsychopharmacological effects of the ayurvedic nootropic Bacopa monniera Linn. (Brahmi)," Indian Journal of Pharmacology, vol. 29, no. 5, pp. S359-S365, 1997.

[24] P. J. Nathan, J. Clarke, J. Lloyd, C. W. Hutchison, L. Downey, and C. Stough, "The acute effects of an extract of Bacopa monniera (Brahmi) on cognitive function in healthy normal subjects," Human Psychopharmacology, vol. 16, no. 4, pp. 345-351, 2001.

[25] C. Stough, J. Lloyd, J. Clarke et al., "The chronic effects of an extract of Bacopa monniera (Brahmi) on cognitive function in healthy human subjects," Psychopharmacology, vol. 156, no. 4, pp. 481-484, 2001.

[26] S. Sinha and P. Chandra, "Removal of $\mathrm{Cu}$ and $\mathrm{Cd}$ from water by Bacopa monnieri L," Water, Air, and Soil Pollution, vol. 51, no. 3-4, pp. 271-276, 1990.

[27] M. Gupta, S. Sinha, and P. Chandra, "Uptake and toxicity of metals in Scirpus lacustris L. and Bacopa monnieri L," Journal of Environmental Science and Health A, vol. 29, no. 10, pp. 21852202, 1994.

[28] S. Sinha, M. Gupta, and P. Chandra, "Bioaccumulation and biochemical effects on mercury in the plant Bacopa monnieri L," Environ Toxicol Water Qual, vol. 11, pp. 105-112, 1996.

[29] S. Sinha, "Accumulation of $\mathrm{Cu}, \mathrm{Cd}, \mathrm{Cr}, \mathrm{Mn}$ and $\mathrm{Pb}$ from artificially contaminated soil by Bacopa monnieri," Environmental Monitoring and Assessment, vol. 57, no. 3, pp. 253-264, 1999.

[30] G. Ali, P. S. Srivastava, and M. Iqbal, "Responses of Bacopa monniera cultures to cadmium toxicity," Bulletin of Environmental Contamination and Toxicology, vol. 66, no. 3, pp. 342-349, 2001.

[31] S. Mishra, S. Srivastava, R. D. Tripathi, R. Govindarajan, S. V. Kuriakose, and M. N. V. Prasad, "Phytochelatin synthesis and response of antioxidants during cadmium stress in Bacopa monnieri L.", Plant Physiology and Biochemistry, vol. 44, no. 1, pp. 25-37, 2006.

[32] S. Singh, S. Eapen, and S. F. D'Souza, "Cadmium accumulation and its influence on lipid peroxidation and antioxidative system in an aquatic plant, Bacopa monnieri L," Chemosphere, vol. 62, no. 2, pp. 233-246, 2006.

[33] D. R. Hoagland and D. I. Arnon, The Water-Culture Method For Growing Plants Without Soil, vol. 347, California Agricultural Experiment Station Publications, 1950.

[34] D. I. Arnon, "Copper enzyme in isolated chloroplast: polyphenol oxidase in Beta vulgaris," Plant Physiology, vol. 24, pp. 1-15, 1949.

[35] O. H. Lowry, N. J. Rosebrough, A. L. Farr, and R. J. Randall, "Protein measurement with the Folin phenol reagent," The Journal of biological chemistry, vol. 193, no. 1, pp. 265-275, 1951.

[36] J. H. Zar, Biostatistical Analysis, Prentice Hall Publishers, 1974.

[37] A. Haag-Kerwer, H. J. Schäfer, S. Heiss, C. Walter, and T. Rausch, "Cadmium exposure in Brassica juncea causes a decline in transpiration rate and leaf expansion without effect on photosynthesis," Journal of Experimental Botany, vol. 50, no. 341, pp. 1827-1835, 1999.

[38] W. T. Griffiths, "Characterization of the terminal stages of chlorophyll(ide) synthesis in etioplast membrane preparations," Biochemical Journal, vol. 152, no. 3, pp. 623-635, 1975.

[39] M. C. Romero-Puertas, M. Rodríguez-Serrano, F. J. Corpas, M. Gómez, L. A. Del Río, and L. M. Sandalio, "Cadmium-induced subcellular accumulation of $\mathrm{O}_{2}$.- and $\mathrm{H}_{2} \mathrm{O}_{2}$ in pea leaves," Plant, Cell and Environment, vol. 27, no. 9, pp. 1122-1134, 2004.

[40] R. A. Mayes, A. W. McIntosh, and V. L. Anderson, "Uptake of cadmium and lead by a rooted aquatic macrophyte (Elodea canadensis)," Ecology, vol. 58, no. 5, pp. 1176-1180, 1977.

[41] M. Nakada, K. Fukaya, S. Takeshita, and Y. Wada, “The accumulation of heavy metals in the submerged plant (Elodea nuttallii)," Bulletin of Environmental Contamination and Toxicology, vol. 22, no. 1-2, pp. 21-27, 1979.

[42] H. Kay, W. T. Haller, and L. A. Garrard, "Effects of heavy metals on water hyacinths (Eichhornia crassipes (mart.) solms)," Aquatic Toxicology, vol. 5, no. 2, pp. 117-128, 1984.

[43] R. Nir, A. Gasith, and A. S. Perry, "Cadmium uptake and toxicity to water hyacinth: effect of repeated exposures under controlled 
conditions," Bulletin of Environmental Contamination and Toxicology, vol. 44, no. 1, pp. 149-157, 1990.

[44] P. Garg, R. D. Tripathi, U. N. Rai, S. Sinha, and P. Chandra, "Cadmium accumulation and toxicity in submerged plant Hydrilla verticillata (L.F.) Royle," Environmental Monitoring and Assessment, vol. 47, no. 2, pp. 167-173, 1997.

[45] R. R. Brooks, "General introduction," in Plants That Hyperaccumulate Heavy Metals, R. R. Brooks, Ed., pp. 1-14, CAB International, Wallingford, UK, 1998.

[46] G. E. Trease and G. E. Evans, Text Book of Pharmacognosy, Tindall and Cox, London, UK, 2nd edition, 1989.

[47] A. Mithöfer, B. Schulze, and W. Boland, "Biotic and heavy metal stress response in plants: evidence for common signals," FEBS Letters, vol. 566, no. 1-3, pp. 1-5, 2004.

[48] V. Rai, P. Vajpayee, S. N. Singh, and S. Mehrotra, "Effect of chromium accumulation on photosynthetic pigments, oxidative stress defense system, nitrate reduction, proline level and eugenol content of Ocimum tenuiflorum L," Plant Science, vol. 167, no. 5, pp. 1159-1169, 2004.

[49] V. Rai, S. Khatoon, S. S. Bisht, and S. Mehrotra, "Effect of cadmium on growth, ultramorphology of leaf and secondary metabolites of Phyllanthus amarus Schum. and Thonn," Chemosphere, vol. 61, no. 11, pp. 1644-1650, 2005.

[50] S. Sinha and R. Saxena, "Effect of iron on lipid peroxidation, and enzymatic and non-enzymatic antioxidants and bacoside: a content in medicinal plant Bacopa monnieri L," Chemosphere, vol. 62 , no. 8 , pp. 1340-1350, 2006. 

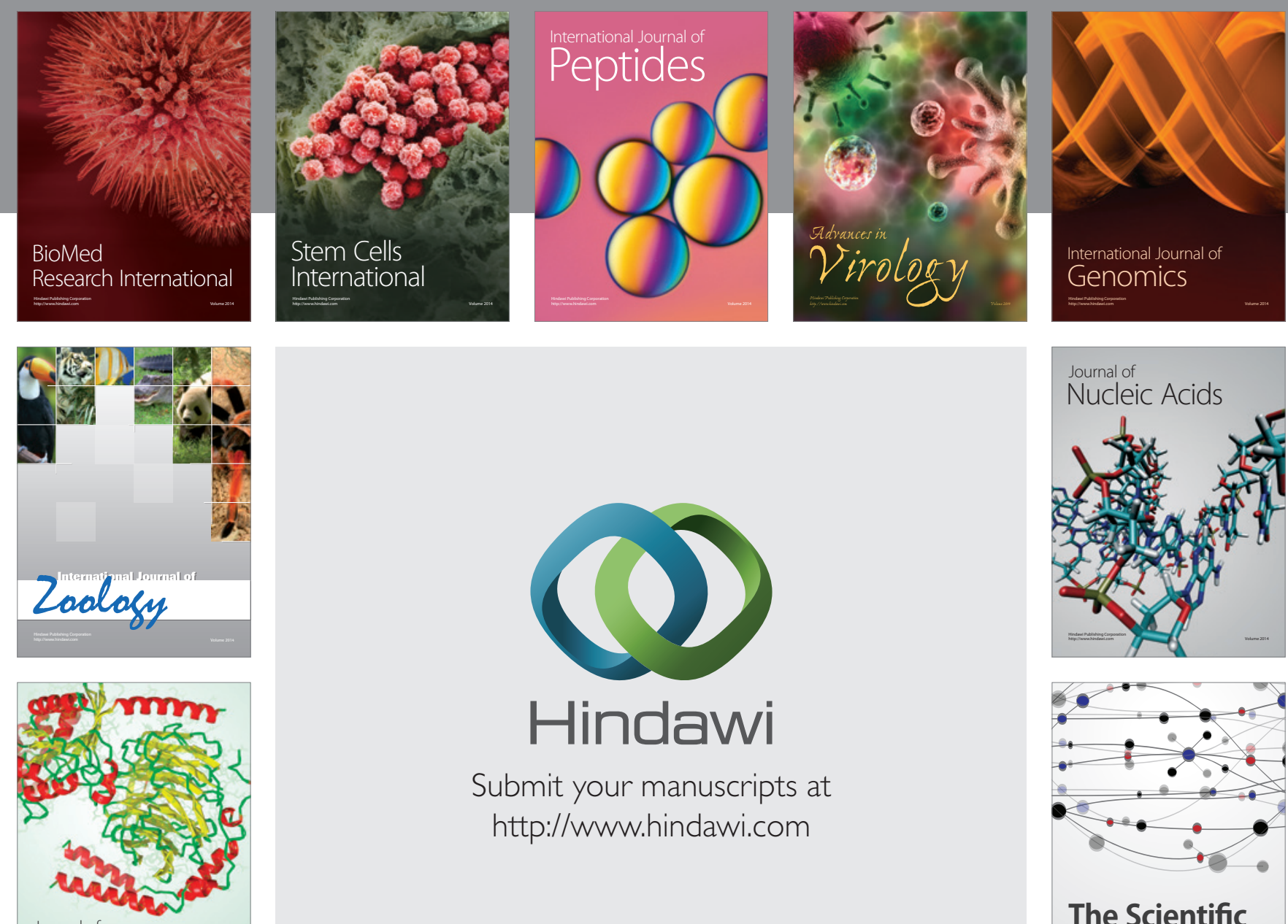

Submit your manuscripts at

http://www.hindawi.com

Journal of
Signal Transduction
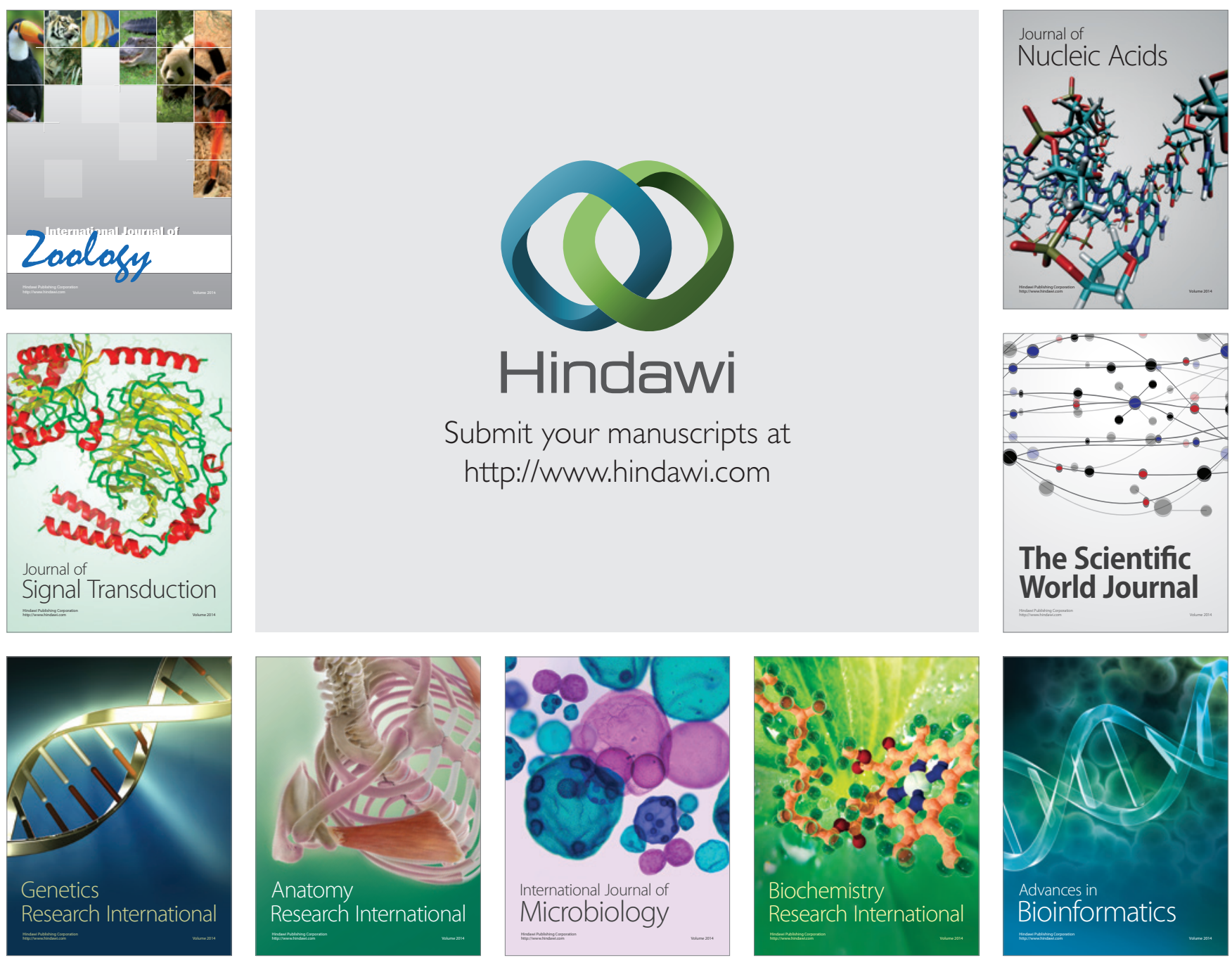

The Scientific World Journal
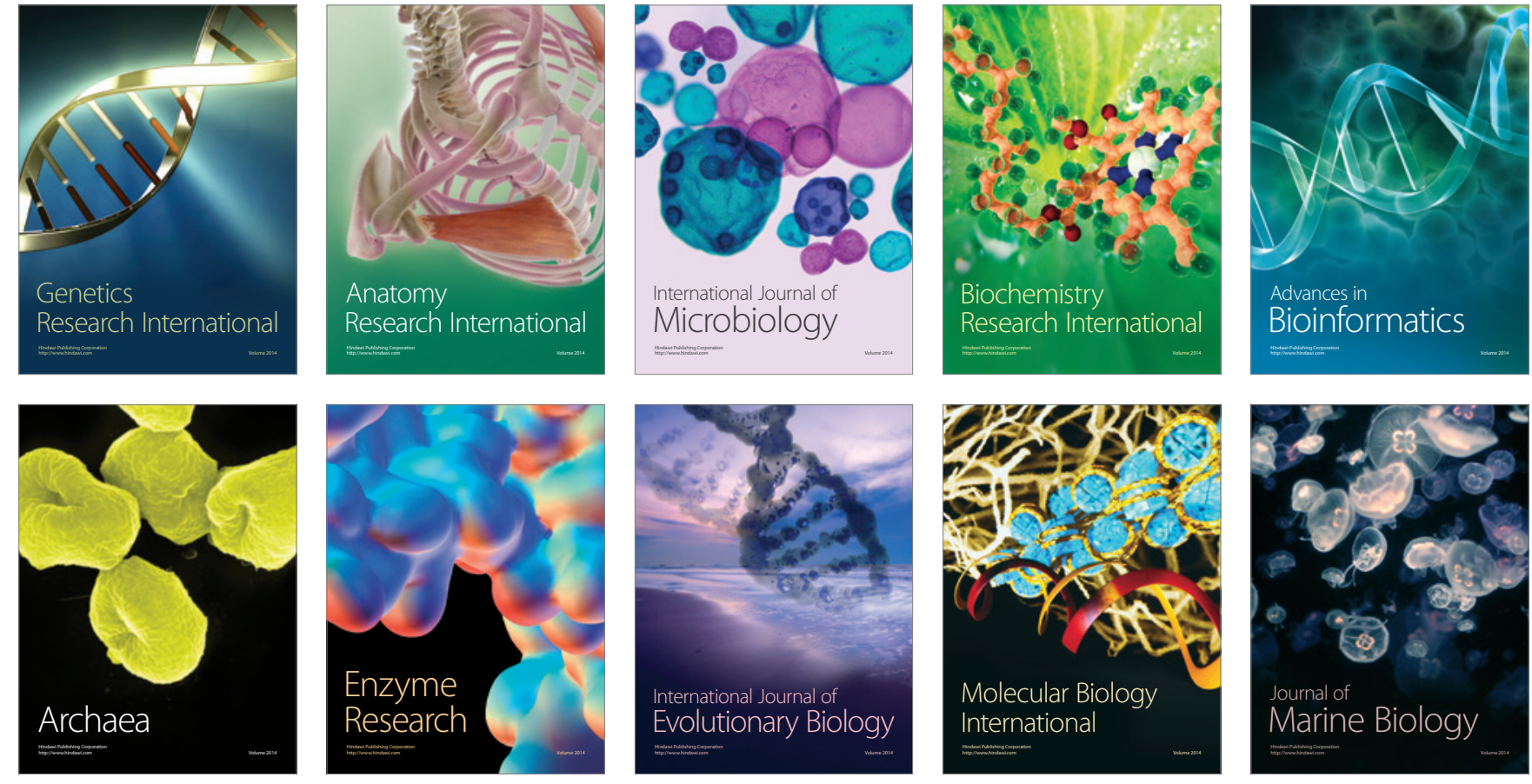